\title{
The practical teaching reform of the ideological and political theory course in University based on CDIO
}

\author{
Jie Li, Qijie Wu, Jingyang Yu \\ School of Marxism, Harbin Commercial University \\ Harbin, Heilongjiang, China \\ jill_lijie@163.com
}

\begin{abstract}
The CDIO educational model is the latest achievement of international advanced engineering educational reform which is widely applied in higher education. It is a new innovative exploration that the CDIO educational concepts are implanted and penetrated into the practical teaching reform of the ideological and political theory course in university, which is an effective way to promote its pertinence and effectiveness. This paper tries to construct the integrative practical teaching system which makes links and interactions inside and outside class though the wide angle, multi-level and comprehensive practical teaching reform.
\end{abstract}

Keywords-practical teaching; the ideological and political theory course; CDIO

\section{INTRODUCTION}

The ideological and political theory course is the essential characteristics of socialist higher education and the main channel and position which guide the college students to set up the scientific world outlook, the view of life and values for the task of civilizing, cultivating and shaping people. However, the actual effect is not ideal. The phenomenons of "listen carefully the professional course, listen casually the elective course, and listen disgustingly the political course" still exist in the part of the students. The factors that caused this situation are complicated, but it is a very important reason that the lack of effective combination between the theory and practice. The practice teaching is an extension of the theory teaching. It is an important segment to foster and improve the comprehensive quality of students by the principle of theory with practice. Therefore, it is the important content for the ideological and political theory course teaching reform and an effective way to improve the pertinence, timeliness and teaching effect.

\section{The Deficiency Existing IN Practice Teaching IN THE CURRENT}

\section{A. There Is Erroneous Zone in Teaching Concepts}

Due to the influence of the traditional exam-oriented education, people just regard the ideological and political theory course as a pure theory course which is paid more attention to teaching in rather than outside class, theory rather than practice, preach rather than nurturance, moralization rather than internalization. It is emphasized to instill the knowledge and theory in book, while ignored to internalize and externalize the practical comprehension and ideological quality. Those lead to the students' knowing separate from behavior and belief in their ideology and politics, ethics and values. The effectiveness of the ideological and political theory course is inevitable lacking.

\section{B. The Content and form is Simple}

It makes the practice teaching often stays in visiting, inspection, social investigation, volunteer service and other such activities because of the understanding that practice teaching is equivalent to social practice teaching. So the content and form of practice teaching is too single. In addition, because the problems such as tight money, the shortage of practical teaching base, the difficult teaching organization, especially the students' safety, are limited, when universities organized the practice teaching outside campus, they often use the way of a few backbone of minority students attended, which lead to students' enthusiasm is not high and nationality is not wide, and the practice teaching has obvious locality and bias.

\section{The Policyguarantee is not Enough}

Due to the factors such as attention degree is not enough, measures are not in place, and conditions are restricted, etc, it doesn't set up the perfect teaching system and guarantee mechanism: It doesn't form the pattern that the party and government's departments manage together under the party committee's leadership; The phenomenon is often appeared that lack of effective communication between the department of theoretical teaching and student affairs office, the communist youth league, the propaganda department and other departments which do their own things; The fund input is obviously insufficient; It doesn't form the combination of the full-time and part-time teachers team of practice teaching, now the teachers mainly undertake theoretical teaching task and have not too much energy for practice teaching and research; The resources' development of social practice teaching is insufficient and the functional practice teaching base is not established, and so on.

\section{The Teaching Organization is Weak}

In the practice teaching, there is no effective mechanism of management and normative organization and arrangement with great randomness, contingency and subjectivity: There are no specific teaching goals and outline, the teaching hours and content are not normative; 
There are no clear teaching requirements and standards; There are no concrete standards of assessment and evaluation. Even though universities reasonably allocate the hours and credit between the theory teaching and practice teaching according to the personnel training requirements of the ministry of education to a scale, at last, it becomes a synonym for reducing its total hours in fact because of the "three no", the organization and management of practice teaching is not in place and the ideological and political theory course is divided into "in class" and "outside class" by some universities. This kind of practice teaching is often become a mere formality, and it is more impossible to set up persistent mechanism of practice education.

\section{THE REFERENCE VALUE OF CDIO}

CDIO just is practice-centered, design-oriented and ability-targeted throughout linking theory with practice and integration. [1]Based on the concept, the ideological and political theory course should also strengthen the social practice, innovate in the practical mode, and better realize the social value. Therefore we try to expand the teaching space, integrate various resources, make links and interactions inside and outside class, and construct the integrative practical teaching system.

The CDIO educational mode is an acronym namely Conceive-Design-Implement-Operate, which is the latest achievement of international advanced engineering educational reform. CDIO's principle is simple, content is inclusive and strong adaptability, method is experiential , that means, it takes the project as the prime mover and lets the students learn by doing. [2]Therefore, it is very suitable for the practical teaching reform of the ideological and political theory course.

CDIO thinks that the students should not only passively accept the teaching plan decided by the teacher, but also actively participate and choose it in the process, and teaching is the process of transferring knowledge to ability. The teacher teaches the students some professional and technical knowledge, at the same time, pays more attention to train their comprehensive abilities. [3]

\section{THE PRACTICAL TEACHING REFORM BASED ON CDIO}

Based on CDIO concepts, we can in a broad sense analyze the meaning of the practical teaching of the ideological and political theory course, which should be the sum of a variety of teaching methods which combines closely theory and practice, classroom and society and study and research, and train students' practical ability such as how to analyze problems by theories and study and solve problems independently, etc. [4] Therefore, the practical teaching of the ideological and political theory course should include four main forms: in-class practice, in-school practice, social practice and scientific research practice.

We can construct the basic framework of practical teaching system by CDIO as shown in figure:

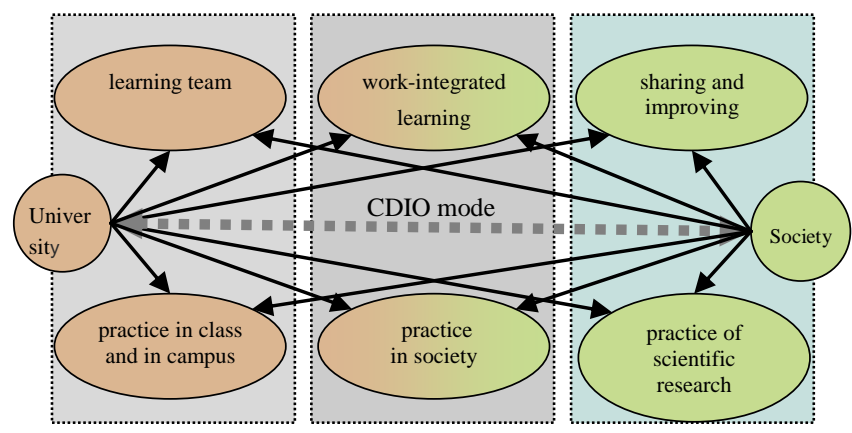

\section{A. The Practical Teaching in Class}

We actively carry out the practical teaching in class to strengthen the recognition link in accord with the theoretical teaching. The practical teaching in class is superior to in society in the respect of the flexibility of choice and the link of content. Essentially, the practical teaching in class is more suitable for the ideological and political theory course, and it has the universality of participation and the persistence and continuity of operation. [5] Its forms include the discussions in class, the topic teaching, the case analysis, the scene simulation, the ectopic teaching between the teacher and students, and the traditional answer, debates, speech, inspiration, and so on. Based on "the projectized mode" of CDIO, in the way of group cooperative learning, we carry out the interactive teaching practice in class which takes students as the main body and makes the theory concrete, the opinion considerate, and the process interact. We construct the benign interactive platform between the "teaching" and "learning", "doing" and "studying".

\section{B. The Practical Teaching in Campus}

We adhere to the idea that "every tree and bush are education", take various field and chamber in campus as the platform, the students' community as the supporting, and the important festivals, Remembrance Day and major events at home and abroad as the carrier to implement widely the second classroom activities and strengthen the understanding and experiential link. Such as we organized red series project activities, the specific situation is as follows:

\section{1) Red dialogue:}

We carry out the communication activities of reading, understanding and discussing classics, which take Marxism theory as the backing and the student as the main body. We recommend and introduce the red classics about China's revolution, construction and reform to students, let them realize self-education and have a dialogue to the great men with the mind. At the same time, we carry out different levels of research activities by some exchange form, such as discussion, debates, reports, and so on.

\section{2) Red promotion:}

In the important historical days, especially great influencing days in students, such as the Youth Day, the Party's birthday, the National Day, 12.9 Movement Day, and so on, on the one hand, we carry on school-wide red theme lectures, on the other hand, organize the students' theme speech, composition and other activities. In addition, we 
have established Party lessons as fixed long-acting model, and give the red education to the probationary Party members and the activists who eager to join the party. We promote the conventional teaching to party-lesson teaching which sublimates students' ideological and theoretical accomplishment.

\section{3) Red guidance:}

It is necessary to give them the positive guidance from the teacher in the students' researching process in order to help them discern what is right or wrong, stand firm and understand and solve problems correctly. Because of the limit of the teaching content and time in class, in addition to the teacher's guidance in class, we have set up the corresponding long-term mechanism, which is regularly answering questions for students in the fixed place and time, and setting up long-term contact with the students, such as the fixed E-mail and other network communication. So we can grasp the students' psychological dynamic and keep track of their class's feedback, so that the teacher enrich and adjust the teaching contents in time to make up for the deficiency of the teaching in class.

Through the red series activities, firstly, the students felt the great in the red atmosphere. Making use of the "red" symbol meaning: revolution, struggle and enterprising, we let the contemporary college students understand and grasp that the revolutionary martyrs and great man have made the great contribution for our Chinese nation in Chinese revolution, construction and reform by Marxist theory as the guide, so as to inspire us to inherit and carry forward the red spirit and character in the new era.

Secondly, through the learning, researching and communicating about the Marxist classic that reflect the red spirit and character and the students' widely participating and practicing, there is a kind of cultural atmosphere of talking about and loving "the red" in our campus, so as to purify the mind, edify the sentiment and cast the high quality.

In addition, we can also lead the students to participate in the campus's public activities, the organization of communities, and the construction of the campus's culture, so that spread out the ideological and political education from in the course to the broader space and levels, and make the students improve the practical abilities in their personal experience and feelings.

\section{The Practical Teaching in Society}

In order to deepen the practical link, we organize the students to visit off campus and research related social problems. Through social investigation, the students can obtain first-hand materials and see the profound changes for themselves in people's life, employment and society with the opening and reform, so as to enhance the persuasiveness and appeal of theory. After the investigating activities, we organize the students to write reports or results, and held a public lecture or discussion to talk about knowledge and exchange experiences so as to let them combine the theoretical study and practical experience, then improve their ability of understanding, analyzing and solving problems. However, this kind of social practice is often limited by various factors such as money, time, place, safe, the quantity of students and difficult organization, etc. But also it is unable to realize if we only depend on the teacher of the course who cannot be fully competent in the respect of the energy or ability. Therefore, we gradually build a great moral educational system by the integration of various educational resources inside and outside campus, which establishes the cooperation between colleges and enterprises, the links between schools and regions, the interaction between universities and communities outside campus and puts the teacher of the course as the main position and different levels' team of doing students' work as the auxiliary under the leadership of the Party committee inside campus. It is also necessary to form the integrative favorable education mechanism with "full participation, full attention, full implementation" to provide powerful organizational guarantee for the reform. [5]

It includes the following three ways:

Firstly, we carry on the students' summer social practice activities together with the Youth corps committee, the students' affairs office and other departments of doing students' work, thus form the join forces mechanism of education. Through the social investigation, visit, services, being the volunteer and other social practice activities, we guide the students to combine the knowledge in book with the social practice, the external education with their own experience to train their moral practice ability, to unify the ethical knowledge and moral behavior.

Secondly, we set up the practice base of the ideological and political theory course, and actively accept the social various aspects of education power, radiate the ideological and political education to external practice teaching by the way of the production-education combination and the university-enterprise cooperation, etc .

Thirdly, we penetrate the ideological and political education in students' professional practice and the process that students participate in the technology innovation of enterprise. We should create the condition to make students participate in social life and develop the technical service. Through the deep professional practice, we let students more fully understand the relationships between individuals and society in order to verify and reflect on the scientific what they have learned.

\section{The Practical Teaching of Scientific Research}

The practical teaching of scientific research is the indispensable basic form to play the main body role of university students. According to the connotation of the practical teaching, the practical teaching of scientific research is one of the most basic and important forms in the practical teaching of the ideological and political theory course.

Under the guidance of the teacher, students choose and determine the research topic from the social development and lives combined with what they learned in class, then collect data and carry out social investigation, at last write research reports and report results. That is to say, it is the research-based learning in a similar way of scientific research. It is an open, inquiry-based and student-oriented 
learning activity in which the teacher is only the organizers, participants and mentor.

\section{SUMMARY}

Though the wide angle, multi-level and comprehensive practical teaching reform, the college students can go into the society from classroom and treat on the social reality objectively and rationally, thus form their independent judgment ability and individual thinking. At the same time, they experience the achievement of reformation and opening and the Party's ruling ability. There is no doubt that they can deepen the understanding of Marxist theory and strengthen the sense of identity and understanding about the party's theory and policy, thus more love the Party and firmly believe the socialist system and make them improve their political ability and literacy.

\section{ACKNOWLEDGEMENT}

This research was financially supported by the Teaching Reform Project of Colleges and Universities in Heilongjiang Province of China (Grant NO.JG2012010303) and key project funds for Heilongjiang provincial education \& science planning project (GBB1212001).

\section{REFERENCES}

[1] Lin Yizhen, Analysing the CDIO Model for Higher Engineering Education, Journal of Harbin University, vol.4, pp. 137-140, 2008.

[2] Sun Ming, Liu WeiBin, Wang YuFen. Rearch on Teaching Mode of U niversities Urban Planning Specialty Graduational Design based onC DIO . The forest engineering, vol.5, pp. 92-96, 2012.

[3] LI Jie, The teaching reform of the ideological and political theory course in University based on CDIO educational concepts, $20133^{\text {rd }}$ International Conference on Applied Social Science, vol.2, pp.214$218,2013$.

[4] LIU Shi-hua,WU Shao-yu, Limitations and Options of Field Work for Courses of Ideological and Political Education, Teaching and Research, vol.4, pp. 87-90, 2008.

[5] Lu Zhimei, Try to talk about the college ideological and political theory course practice teaching reform of Northeast Forestry University - and "three three" type practice teaching mode exploration, Leading Journal of Ideological \& Theoretical Education, vol.6, pp. $75-79,2010$

[6] GUO Hua-hong, University Ideological and Political Theory Lesson Practice Teaching Intension and System Construction, Higher Education Forum, vol.8, pp. 40-42, 2010. 